Research Article

\title{
Evaluation of association of DRD2 TaqlA and -141C InsDel polymorphisms with food intake and anthropometric data in children at the first stages of development
}

\author{
Vanessa Feistauer ${ }^{1}$, Márcia R. Vitolo ${ }^{2}$, Paula D. B. Campagnolo ${ }^{3}$, Vanessa S. Mattevi ${ }^{1,4}$ and Silvana \\ Almeida ${ }^{1,4}$ \\ ${ }^{1}$ Laboratório de Biologia Molecular, Programa de Pós-Graduação em Biociências, Universidade Federal de \\ Ciências da Saúde de Porto Alegre, Porto Alegre, RS, Brazil. \\ ${ }^{2}$ Departamento de Saúde Coletiva, Universidade Federal de Ciências da Saúde de Porto Alegre, Porto \\ Alegre, RS, Brazil. \\ ${ }^{3}$ Curso de Nutrição, Universidade do Vale do Rio dos Sinos, São Leopoldo, RS, Brazil. \\ ${ }^{4}$ Departamento de Ciências Básicas da Saúde, Universidade Federal de Ciências da Saúde de Porto Alegre, \\ Porto Alegre, RS, Brazil.
}

\begin{abstract}
The reward sensation after food intake may be different between individuals and variants in genes related to the dopaminergic system may indicate a different response in people exposed to the same environmental factors. This study investigated the association of TaqIA (rs1800497) and -141C InsDel (rs1799732) variants in DRD2/ANKK1 gene with food intake and adiposity parameters in a cohort of children. The sample consisted of 270 children followed until 7 to 8 years old. DNA was extracted from blood and polymorphisms were detected by PCR-RFLP analysis. Food intake and nutritional status were compared among individuals with different SNP genotypes. Children carrying the $A 1$ allele ( $T a q \mathrm{IA}$ ) had higher energy of lipid dense foods (LDF) when compared with A2/A2 homozygous children at 7 to 8 years old (GLM $p=0.004$; Mann Whitney $p=0.005)$. No association was detected with $-141 \mathrm{C} / \mathrm{ns} / \mathrm{Del}$ polymorphism. To our knowledge, this is the first association study of the DRD2 TaqIA and $-141 \mathrm{C}$ Ins/De/polymorphism with food intake and anthropometric parameters in children. DRD2 TaqIA polymorphism has been associated with a reduction in $D_{2}$ dopamine receptor availability. Therefore, the differences observed in LDF intake in our sample may occur as an effort to compensate the hypodopaminergic functioning.
\end{abstract}

Keywords: Child obesity, DRD2 polymorphisms, food intake.

Received: July 4, 2017; Accepted: January 9, 2018.

\section{Introduction}

The prevalence of childhood overweight and obesity had a dramatic increase between 1990 and 2010, rising from $4.2 \%$ to $6.7 \%$, and it is estimated that in 2020 the rate will be $9.1 \%$, or approximately 60 million children (de Onis et al., 2010). The obesity prevalence in developed countries is twice higher than in developing countries. However, most of the affected children (35 million) live in developing countries (de Onis et al., 2010). Moreover, the relative increase rate of obesity in recent decades was higher in developing countries $(+65 \%)$ than in developed countries (+48\%) (de Onis et al., 2010; Oggioni et al., 2014). Obese children are more likely to become obese adults, and have

Send correspondence to Silvana Almeida. Departamento de Ciências Básicas da Saúde, Universidade Federal de Ciências da Saúde de Porto Alegre, Rua Sarmento Leite, 245, 90050-170 Porto Alegre, RS, Brazil. E-mail: salmeida@ufcspa.edu.br higher risk of developing coronary heart diseases and other related diseases, which diminish life expectancy (Must, 1996; Rossner, 1998; Berenson, 2012). Insulin resistance, metabolic syndrome, and type 2 diabetes are also consequences of childhood obesity (Gupta et al., 2012).

Some factors contribute to overweight and obesity, such as low physical activity, high intake of high fat and sugar foods, change from the rural lifestyle to the urban, sociocultural factors, age, gender, and genetic factors (Popkin, 2006; Gupta et al., 2012; Oggioni et al., 2014). The sensation of reward after food intake, especially of palatable foods, may be different among individuals and might cause different amounts of food ingestion (Berridge et al., 2010). The dopaminergic system regulates food intake through a reward system, and although its function in eating disorders is poorly understood, it is known that the use of dopamine $\mathrm{D}_{2}$ receptors agonists decreases food intake in rats (Terry et al., 1995). A study that analyzed images via 
Positron Emission Tomography (PET) scans shows that obese individuals have low concentration of striatal D2 dopamine receptors as a mechanism of downregulation due to high levels of dopamine, indicating that the reduction of these receptors could be associated with an addictive behavior also observed in drug users (Wang et al., 2001). DRD2/ANKK1 gene polymorphisms alter the density of dopamine receptors, and thus may explain the different food intake levels in individuals exposed to the same environmental factors (Stelzel et al., 2010).

Several studies have associated the TaqIA (rs1800497) polymorphism with obesity, body mass index (BMI), and food intake (Barnard et al., 2009; Winkler et al., 2012; Cameron et al., 2013; Carpenter et al., 2013). However, to our knowledge, there is no study linking the $-141 \mathrm{C}$ Ins/Del (rs1799732) polymorphism to obesity, although it was associated with other pathologies such as alcoholism and schizophrenia (Jonsson et al., 1999a; Johann et al., 2005; Lafuente et al., 2008a,b). Therefore, the objective of the present study was to analyze the association of TaqIA and -141C Ins/Del polymorphisms with adiposity parameters and food intake of children.

\section{Materials and Methods}

\section{Subjects}

The sample consisted of 270 children followed until 7 to 8 years old on average. The nutritional and anthropometrics data were collected at 12 to 16 months, 3 to 4 and 7 to 8 years. The children included in the present study participated in a randomized controlled trial of dietary counseling on breast feeding and diet during the first year of life. The trial consisted of 500 children, randomized in a control or intervention group, of which mothers received a dietary advice about breastfeeding and complementary feeding during home visits in children's first year of life. This dietary advice was based on the "Ten steps to Healthy Feeding", a Brazilian national health policy for primary care, supported by World Health Organization (2006). More information of the first phase of the study can be found elsewhere (Vitolo et al., 2010), but in Table 1 we described the main characteristics of the sample. A substantial reduction of the sample occurred throughout the study and the main reason for the losses was the inability to locate the participants' homes, usually due to the family moving to another city. Other reasons for losses were refusal to continue and children or maternal death. This intervention was not the primary objective of the present research and the participation in the intervention or control group was used as a confounding factor in statistical analyses.

Ethnicity was defined by the interviewer by skin color (i.e., whites and non-whites). More details of the traits studied are described elsewhere (Galvão, 2012; Louzada et al., 2012; Fontana et al., 2015; Miranda et al., 2015). This study was conducted according to the guidelines of the
Table 1 - Main characteristics of the sample.

\begin{tabular}{|c|c|}
\hline \multicolumn{2}{|l|}{ Characteristics } \\
\hline Ethnicity (whites) ${ }^{a}$ & $210(77.8)$ \\
\hline Sex (boys) ${ }^{\mathrm{a}}$ & $149(55.2)$ \\
\hline \multicolumn{2}{|l|}{12 to 16 months } \\
\hline Child's BMI (Z-score) ${ }^{\mathrm{b}}$ & $0.59 \pm 1.07$ \\
\hline Average daily energy intake $(\mathrm{kcal})^{\mathrm{b}}$ & $948.51 \pm 398.56$ \\
\hline \multicolumn{2}{|l|}{3 to 4 years } \\
\hline Child's BMI (Z-score) ${ }^{\mathrm{b}}$ & $0.27 \pm 1.16$ \\
\hline Average daily energy intake $(\mathrm{kcal})^{\mathrm{b}}$ & $1520.21 \pm 391.36$ \\
\hline Sugar dense food intake (SDF; kcal) ${ }^{b}$ & $105.94 \pm 86.15$ \\
\hline Lipid dense food intake (LDF; kcal) ${ }^{b}$ & $177.18 \pm 190.81$ \\
\hline $\begin{array}{l}\text { Average daily energy intake per kilogram } \\
(\mathrm{kcal} / \mathrm{kg})^{\mathrm{b}}\end{array}$ & $91.23 \pm 27.27$ \\
\hline \multicolumn{2}{|l|}{7 to 8 years } \\
\hline Child's BMI (Z-score) ${ }^{\mathrm{b}}$ & $0.41 \pm 1.38$ \\
\hline Average daily energy intake $(\mathrm{kcal})^{\mathrm{b}}$ & $1564.54 \pm 381.34$ \\
\hline Sugar dense food intake (SDF; kcal) ${ }^{\mathrm{b}}$ & $230.02 \pm 194.97$ \\
\hline Lipid dense food intake (LDF; kcal) ${ }^{\mathrm{b}}$ & $85.10 \pm 80.33$ \\
\hline $\begin{array}{l}\text { Average daily energy intake per kilogram } \\
(\mathrm{kcal} / \mathrm{kg})^{\mathrm{b}}\end{array}$ & $59.75 \pm 18.10$ \\
\hline
\end{tabular}

${ }^{\mathrm{a}}$ Data are presented as \% (n).

${ }^{\mathrm{b}}$ Data are presented as mean \pm standard deviation.

Declaration of Helsinki. The study protocol was approved by the Ethics Committee of the Universidade Federal de Ciências da Saúde de Porto Alegre (n. 286/06), and all participants provided written informed consent before commencing the study.

\section{Nutritional status assessment}

At 12 to 26 months, children were weighted using a portable digital scale (Techline, São Paulo, Brazil) and length was measured by an infant stadiometer (Serwital Inc, Porto Alegre, Brazil). At 3 to 4 and 7 to 8 years, children were weighted using a digital scale (Techline), and height was measured using a stadiometer (SECA, Hamburg, Germany). BMI was calculated [weight $(\mathrm{kg}) /$ height $\left.^{2}\left(\mathrm{~m}^{2}\right)\right]$, and the values were transformed into Z-scores.

\section{Dietary data assessment}

One 24-hour dietary recall was collected for each child at 12 to 16 months, and two 24-hour dietary recalls, on two nonconsecutive days, were collected for each child at the ages of 3 to 4 and 7 to 8 years. The 24-hour dietary recall was carried out by a trained undergraduate nutrition student, and the child's food intake was recorded on the day before the last home visit. A food portion measurement device and the common household measures (e.g. teaspoons, tablespoons, cups) were used to quantify portion sizes. 
Dietary information was entered into the Nutrition Support Program software from the Escola Paulista de Medicina, Federal University of São Paulo, based on the United States Department of Agriculture chemical composition tables. The energy intake was calculated using only one dietary recall or the average of two dietary recalls. The items listed in the response were classified as sugar-dense foods (SDF) if the percentage of simple carbohydrates was higher than 50\% (e.g., soda, Jell-O, candies, and artificially flavored juice) and as lipid-dense foods (LDF) if there was more than $30 \%$ fat (e.g. fried pastries, cookies with fillings, cold cuts and sausages, fried foods, and chocolate).

\section{DNA analyses}

Blood samples for DNA extraction were collected in EDTA tubes $(6 \mathrm{~mL})$. Genomic DNA was extracted from peripheral blood leukocytes by the Lahiri and Nurnberger procedure (Lahiri and Nurnberger, 1991). DRD2/ANKK1 TaqIA (rs1800497) and -141C InsDel (rs1799732) polymorphisms were detected by PCR-RFLP analysis using primer sequences and conditions described by Grandy et al. (1993) and Ohara et al. (1998), respectively. Primers sequences (IDT Coralville, IA, USA) were as follows: TaqIA, forward primer 5'- CACCTTCCTGAGTGTCAT CAA -3' and reverse primer 5'-AGACAACTTGGCCAG CCGTG-3'; -141C InsDel, forward primer 5'-ACTGGC GAGCAGACGGTGAGG and reverse primer 5'TGCGCGCGTGAGGCTGCCGGT. PCR products were digested separately with either TaqI (TaqIA polymorphism) or MvaI (-141C InsDel polymorphism) enzyme (Fermentas, Glen Burnie, MD, USA), according to the manufacturer's instructions. Genotypes were determined after electrophoresis in 2 or $3 \%$ agarose gels that had been stained with ethidium bromide. For the DRD2/ANKK1 TaqIA polymorphism, the $C$ allele contains a TaqI restriction site and is designated as the $A 2$ allele, while the $T$ allele is designated as the $A 1$ allele. For the -141C InsDel polymorphism, the $-141 C^{*}$ Ins allele contains a restriction site for $M v a \mathrm{I}$ while the $-141 C^{*} \mathrm{Del}$ allele does not.

\section{Statistical analyses}

Allele frequencies were estimated by gene counting. A chi-square test for goodness-of-fit was used to determine whether the observed genotype frequency distributions agreed with those expected under Hardy-Weinberg equilibrium. Linkage disequilibrium was estimated using the Haploview software Version 4.2 (Broad Institute, Barrett et al., 2005).

Pearson's chi-squared or Fisher's Exact Test was used to compare genotype or allele frequencies between white and non-white children. Since the first publication of an association study with the TaqIA polymorphism (Blum et al., 1990), and because of the rare occurrence of the $A 1$ allele, genotypes are normally grouped as $A 1$ allele presence or $A 1$ allele carriers ( $A 1 / A 1$ and $A 1 / A 2, \mathrm{n}=102)$, versus
$A 2 / A 2$ homozygotes ( $\mathrm{n}=116$ ). Similarly, due to low frequencies of the $\mathrm{Del}$ allele, genotypes of the -141C InsDel polymorphism were grouped by $\mathrm{Del}$ allele presence or $\mathrm{Del}$ allele carriers (Del/Del and Ins/Del, $\mathrm{n}=61)$, versus Ins/Ins homozygotes $(\mathrm{n}=157)$. All data are presented as mean and standard deviation. Statistical analysis of SDF and LDF variables were performed on natural logarithm transformed data to normalize their distribution. This allowed including these variables in multivariate analysis; non-transformed values are shown in Table 2. Means of food intake (average daily energy intake, SDF, LDF and average daily energy intake per kilogram) and adiposity (BMI Z-score) parameters were compared among genotype groups by a multivariate general linear model (GLM). The multivariate GLM was performed including all dependent continuous variables in one model, using the categorical variables (1) the control or intervention variable of the randomized trial, (2) sex, and (3) ethnicity as covariates, and genotypes of -141C InsDel (rs1799732) and TaqIA (rs1800497) polymorphisms as fixed factors (see Table 2). This first step of the analysis verified whether the group of dependent continuous variables was significantly affected by the group of independent categorical variables. Only LDF intake at 7 to 8 years old was associated with TaqIA polymorphism, and the covariates did not influence this dependent variable. Therefore, to test the association of TaqIA polymorphism alone with LDF intake at 7 to 8 years, we performed a MannWhitney test. A $p$-value of $<0.05$ was considered significant. All tests and transformations were performed using the Statistical Package for Social Sciences, Version 20.0 $\left(\right.$ SPSS $^{\circledR}$, Chicago, IL, USA).

\section{Results}

This longitudinal survey sample was composed of 270 children, 149 (55.2\%) boys and 121 (44.8\%) girls, followed up from 12 to 16 months until 7 to 8 years old (Table 1). Minor allele frequencies (MAF) of the DRD2/ANKK1 gene variants observed in the sample were 0.14 of $D e l$ allele of the-141C InsDel (rs 1799732) polymorphism and 0.28 of $A 1$ allele of the TaqIA (rs1800497) polymorphism, which were intermediary to those described in the 1000 Genomes Project database for European (MAF $0.08(\mathrm{Del})$ and 0.19 $(A 1)$ ) and African (MAF $0.57(D e l)$ and $0.38(A 1))$ populations. All genotype frequencies in this sample were in agreement with those expected under the Hardy-Weinberg equilibrium. The two gene variants were not in linkage disequilibrium $\left(\mathrm{D}^{\prime}=0.3, \mathrm{r}=0\right)$.

In Table 2, anthropometric and food intake variables are shown according to the analyzed polymorphisms. As some children could not be found at the third home visit at 7 to 8 years, and some samples could not be analyzed in the laboratory, the total number of children included in the multivariate analysis is different from the initial sample size. Children carrying the $A 1$ allele (TaqIA rs1800497) had higher energy of LDF when compared with $A 2 / A 2$ ho- 
Table 2 - Food intake and anthropometrics parameters according to polymorphisms in DRD2/ANKK1 gene (-141C Ins/Del and TaqIA) in children at 1, 3 to 4 , and 7 to 8 years old.

\begin{tabular}{|c|c|c|c|c|c|c|}
\hline & \multicolumn{3}{|c|}{$\begin{array}{c}\text {-141C Ins/Del } \\
\text { Genotypes }\end{array}$} & \multicolumn{3}{|c|}{$\begin{array}{c}\text { TaqIA } \\
\text { Genotypes }\end{array}$} \\
\hline & Ins/Ins $(\mathrm{n}=157)$ & $\begin{array}{l}\text { Del carriers } \\
\quad(\mathrm{n}=61)\end{array}$ & $p$ & $A 1$ carriers $(\mathrm{n}=102)$ & $A 2 A 2(\mathrm{n}=116)$ & $p$ \\
\hline \multicolumn{7}{|l|}{12 to 16 months } \\
\hline Average daily energy intake (kcal) & $930.95 \pm 400.09$ & $957.82 \pm 390.89$ & 0.601 & $917.78 \pm 395.82$ & $\begin{array}{c}956.66 \pm \\
398.51\end{array}$ & 0.845 \\
\hline BMI Z-score & $0.60 \pm 1.13$ & $0.48 \pm 1.04$ & 0.609 & $0.52 \pm 1.05$ & $0.62 \pm 1.15$ & 0.436 \\
\hline \multicolumn{7}{|l|}{3 to 4 years } \\
\hline Average daily energy intake (kcal) & $1506.24 \pm 396.82$ & $1579.95 \pm 419.60$ & 0.175 & $1476.62 \pm 337.72$ & $\begin{array}{l}1571.04 \pm \\
450.73\end{array}$ & 0.453 \\
\hline $\operatorname{SDF}(k c a l)^{a}$ & $112.00 \pm 97.91$ & $110.77 \pm 77.42$ & 0.969 & $110.0 \pm 86.95$ & $\begin{array}{c}113.11 \pm \\
97.40\end{array}$ & 0.623 \\
\hline $\operatorname{LDF}(\mathrm{kcal})^{\mathrm{a}}$ & $191.55 \pm 197.10$ & $162.20 \pm 189.60$ & 0.288 & $168.83 \pm 179.06$ & $\begin{array}{c}196.09 \pm \\
208.03\end{array}$ & 0.884 \\
\hline BMI Z-score & $0.27 \pm 0.96$ & $0.28 \pm 1.62$ & 0.839 & $0.29 \pm 1.17$ & $0.25 \pm 1.19$ & 0.774 \\
\hline $\begin{array}{l}\text { Average daily energy intake per } \\
\text { kilogram }(\mathrm{kcal} / \mathrm{kg})\end{array}$ & $91.92 \pm 27.74$ & $94.84 \pm 29.75$ & 0.448 & $89.43 \pm 24.96$ & $95.65 \pm 30.71$ & 0.327 \\
\hline \multicolumn{7}{|l|}{7 to 8 years } \\
\hline Average daily energy intake (kcal) & $1560.73 \pm 355.60$ & $1581.21 \pm 414.36$ & 0.756 & $1581.13 \pm 354.41$ & $\begin{array}{c}1553.56 \pm \\
388.07\end{array}$ & 0.481 \\
\hline $\operatorname{SDF}(\mathrm{kcal})^{\mathrm{a}}$ & $90.52 \pm 75.95$ & $68.03 \pm 58.51$ & 0.164 & $76.97 \pm 62.02$ & $90.60 \pm 79.62$ & 0.847 \\
\hline $\operatorname{LDF}(\mathrm{kcal})^{\mathrm{a}}$ & $238.38 \pm 203.75$ & $223.48 \pm 181.94$ & 0.782 & $282.85 \pm 207.96$ & $\begin{array}{c}191.77 \pm \\
178.34\end{array}$ & $0.004^{\mathrm{b}}$ \\
\hline BMI Z-score & $0.45 \pm 1.26$ & $0.25 \pm 1.65$ & 0.514 & $0.50 \pm 1.36$ & $0.30 \pm 1.40$ & 0.258 \\
\hline $\begin{array}{l}\text { Average daily energy intake per } \\
\text { kilogram }(\mathrm{kcal} / \mathrm{kg})\end{array}$ & $59.99 \pm 17.00$ & $60.97 \pm 20.91$ & 0.861 & $59.83 \pm 17.45$ & $60.65 \pm 18.78$ & 0.739 \\
\hline
\end{tabular}

Data are presented as mean \pm standard deviation.

BMI - body mass index. SDF - sugar dense foods. LDF - lipid dense foods. General Linear Model (GLM) multivariates with the following co-variates: group (intervention or control), sex, ethnicity. ${ }^{\mathrm{a}}$ Statistical analysis from logarithm form, non-transformed values are shown; ${ }^{\mathrm{b}} \mathrm{Mann}-\mathrm{Whitney}$ test $p=0.005$

mozygous children at 7 to 8 years old (multivariate GLM $p=0.004$; Mann-Whitney test $p=0.005$ ). No association was detected among DRD2 -141C Ins/Del polymorphism with food intake and anthropometric parameters.

\section{Discussion}

The dopaminergic pathway has been associated with midbrain reward circuit activation (Roth et al., 2013), and individual differences in $\mathrm{D}_{2}$ receptor expression are hypothesized to contribute to differences in motivated behaviors, such as the motivation to eat (Gluskin and Mickey, 2016). Therefore, polymorphisms of the ANKK1/DRD2 gene are frequently associated with altered perception of food reward and weight gain (Ariza et al., 2012; Muller et al., 2012; Roth et al., 2013). TaqIA is the most commonly tested polymorphism, and is characterized by a single nucleotide change $[\mathrm{C}(A 2) / \mathrm{T}(A 1)]$ located downstream of the termination codon of $D R D 2$ gene at the ankyrin repeat and kinase domain containing 1 (ANKK1) gene (Dubertret et al., 2004; Neville et al., 2004; Li et al., 2015; Ponce et al.,
2016). This SNP produces a Glu713-to-Lys (E713K) substitution in the ANKK1 amino acid sequence, at the eleventh ankyrin, which may alter the affinity of the ANKK1 protein and its substrate (Neville et al., 2004). It is not clear by which molecular mechanisms the ANKK1 protein could be associated with the dopaminergic system and how $A N K K 1$ polymorphic alleles would impact addiction vulnerability. However, ANKK1 and DRD2 genes belong to the same gene cluster, the NTAD cluster, an ancient cluster of which genes are apparently co-regulated and may have emerged when the central nervous system became more complex (Mota et al., 2012). Since genes of related function are sometimes found in the same cluster, it is possible that ANKK1 is somehow involved in the dopaminergic reward processes via a signal transduction pathway (or other cellular response) (Neville et al., 2004). A few in vitro studies with $A N K K 1$ gene mRNAs and proteins were able to show a potential connection between this gene and the dopaminergic system (Hoenicka et al., 2007; Garrido et al., 2011). 
In our sample, the $A 1$ allele (TaqIA rs1800497) was found associated with higher intake of LDF when compared with children $A 2 / A 2$ homozygous at 7 to 8 years. This allele has been associated with a reduction in $\mathrm{D}_{2}$ receptor availability (Pohjalainen et al., 1998; Ritchie and Noble, 2003; Eisenstein et al., 2016). Stice et al. (2008) found that the dorsal striatum is less responsive to food reward in obese relative to lean individuals, probably because obese individuals have reduced $\mathrm{D}_{2}$ receptor density that compromises dopamine signaling. This hypodopaminergic functioning or reward deficiency syndrome may induce obese patients to overeat in an effort to compensate for this reward deficit; several studies are consistent with this theory (van Strien et al., 2010; Duran-Gonzalez et al., 2011; Winkler et al., 2012; Cameron et al., 2013). van Strien et al. (2010) associated the $A 1$ allele with an increase in emotional eating in Dutch adolescents. The $A 1$ allele was also most frequent in young obese Mexican-American subjects than in non-obese, as well as subjects with central-obesity versus subjects with no central-obesity (Duran-Gonzalez et al., 2011). Winkler et al. (2012) observed in an intervention study that carriers of the $A 1$ allele had a higher BMI at all time-points (baseline, after weight loss, and after weight maintenance), and showed less overall weight loss. Similarly, Cameron et al. (2013) observed that post-menopausal women carriers of the $A 1$ allele lost significantly less body weight and fat mass than women with the $A 2 / A 2$ genotype after undergoing an intervention-induced weight loss and increased carbohydrate intake. Some studies were not able to find any association of the DRD2 TaqIA polymorphism with adiposity parameters (Hardman et al., 2014).

In the present study, no association was detected between DRD2 -141C Ins/Del polymorphism with food intake and anthropometric parameters, despite previous findings relating Del carriers of the DRD2 -141C Ins/Del polymorphism with higher $\mathrm{D}_{2}$ receptor density (Jonsson et al., 1999b). The DRD2 -141C Ins/Del polymorphism corresponds to a deletion of one cytosine from a run of two cytosines at position -141 of the DRD2 gene (Arinami et al., 1997). This polymorphism has been associated with risk of schizophrenia in different populations (Arinami et al., 1997; Ohara et al., 1998; Jonsson et al., 1999a; Himei et al., 2002; Wu et al., 2005; Lafuente et al., 2008a,b; Cordeiro et al., 2009; Saiz et al., 2010; Xiao et al., 2013; Wang et al., 2016; Zhao et al., 2016), as well as with weight gain (Lencz et al., 2010) and other responses due to schizophrenia drug treatment (Lencz et al., 2006; Zhang et al., 2010). Associations have been described with propensity to alcohol dependence in different populations (Ishiguro et al., 1998; Konishi et al., 2004a,b; Johann et al., 2005; Du and Wan, 2009; Prasad et al., 2010; Lee et al., 2013), suicide attempts (Suda et al., 2009), psychiatric disorders (Kishida et al., 2004; Ujike et al., 2009; Lencer et al., 2014), different responses to medication and higher quit rates in smokers (Lerman et al., 2006). To the best of our knowledge, there is no other study that associated the DRD2 -141C Ins/Del polymorphism with anthropometric parameters or food intake.

The lack of associations in the two other phases of development (12 to 16 months and 3 to 4 years) may have occurred because children at these ages have restricted access to food, and depend on adults for meals, despite their own preferences. Notwithstanding, at 7 to 8 years, children have many opportunities to eat without parental supervision (Briefel et al., 2009), and the differences observed in LDF intake in our sample may have occurrred as an effort to compensate hypodopaminergic functioning.

Palatability is the induced sensitive response of foods that are usually rich in lipids and/or sugar (Cansell and Luquet, 2016). The sense of taste during food ingestion is the most important aspect in the decision to consume or avoid foods (Besnard, 2016). Contrary to sugar, oral fat perception was considered dependent only on its textural and olfactory cues, but recent identification of lipidreceptors in taste buds of both rodents and humans strongly suggests that lipids might also be perceived by the gustatory pathway (Besnard, 2016). Stimulation of taste buds triggers a signaling cascade leading to subsequent neurotransmitter releases in different brain areas responsible for taste perception (e.g., anterior insula, frontal operculum, orbitofrontal cortex, and the mesolimbic system) (Besnard, 2016). The exchange between these areas results in information of the hedonic experience related to the food's taste (Berridge, 1996). Therefore, not only sugar, but also lipids generate a hedonic experience, producing a positive reinforcement that stimulates dopamine secretion in the brain (Salamone, 1994, Volkow et al., 2002), which is a stimulus associated with "wanting" (Berridge et al., 2010). "Wanting" is an incentive salience or motivation for reward triggered by reward-related cues, such as LDF (Berridge et al., 2010). The attribution of incentive salience makes a cue and its reward more attractive, or more "wanted", without being necessarily more "liked" (Berridge et al., 2010). Consistent with our findings, other studies of our group detected associations of palatable food intake with another polymorphism related to the dopaminergic system in children of the same cohort at 12 to 16 months and 3 to 4 years old (Galvão et al., 2012; Fontana et al., 2015). However, further research is needed to confirm the association of DRD2 TaqIA polymorphism with LDF intake and its potential mechanisms.

In summary, our results showed that TaqIA polymorphism may have an influence on the children's eating behavior, due to the presence of the $A 1$ allele associated with lower $\mathrm{D}_{2}$ receptor density that may lead children to compensate the hypodopaminergic functioning with palatable foods. To our knowledge, this is the first association study of the DRD2 TaqIA and -141C Ins/Del polymorphism with food intake and anthropometric parameters in children at the first stages of development. Notwithstanding, it is nec- 
essary to replicate this findings in other populations and identify the mechanisms by which the dopaminergic system may influence food intake. Nevertheless, the investigation of other polymorphisms in this and other genes of the dopaminergic system and their relation to food intake and anthropometric parameters may be interesting.

\section{Acknowledgments}

This work was supported by Conselho Nacional de Desenvolvimento Científico e Tecnológico (CNPq, Brazil; grant number 471186/2009-0), Fundação de Amparo a Pesquisa do Estado do Rio Grande do Sul (FAPERGS, Brazil; grant number 070026-9), Programa de Bolsas CAPES and PIBIC/CNP, and PROAP-CAPES. The authors thank MSc. Ananda Galvão (in memoriam) for her crucial participation in this study.

\section{References}

Arinami T, Gao M, Hamaguchi H and Toru M (1997) A functional polymorphism in the promoter region of the dopamine D2 receptor gene is associated with schizophrenia. Hum Mol Genet 6:577-582.

Ariza M, Garolera M, Jurado M, Garcia-Garcia I, Hernan I, Sanchez-Garre C, Vernet-Vernet M, Sender-Palacios MJ, Marques-Iturria I , Pueyo R, et al. (2012) Dopamine genes (DRD2/ANKK1-TaqA1 and DRD4-7R) and executive function: their interaction with obesity. PLoS One 7:e41482.

Barnard, ND, Noble EP, Ritchie T, Cohen J, Jenkins DJ, Turner-McGrievy G, Gloede L, Green AA and Ferdowsian H (2009) D2 dopamine receptor Taq1A polymorphism, body weight, and dietary intake in type 2 diabetes. Nutrition 25:58-65.

Barrett JC, Fry B, Maller J and Daly MJ (2005) Haploview: Analysis and visualization of LD and haplotype maps. Bioinformatics 21:263-265.

Berenson GS (2012) Health consequences of obesity. Pediatr Blood Cancer 58:117-121.

Berridge KC (1996) Food reward: Brain substrates of wanting and liking. Neurosci Biobehav Rev 20:1-25.

Berridge KC, Ho CY, Richard JM and DiFeliceantonio DM (2010) The tempted brain eats: Pleasure and desire circuits in obesity and eating disorders. Brain Res 1350:43-64.

Besnard P (2016) Lipids and obesity: Also a matter of taste? Rev Endocr Metab Disord 17:159-170.

Blum K, Noble EP, Sheridan PJ, Montgomery A, Ritchie T, Jagadeeswaran P, Nogami H, Briggs AH and Cohn JB (1990) Allelic association of human dopamine D2 receptor gene in alcoholism. JAMA 263:2055-2060.

Briefel RR, Crepinsek MK, Cabili C, Wilson A and Gleason PM (2009) School food environments and practices affect dietary behaviors of US public school children. J Am Diet Assoc 109(2 Suppl):S91-S107.

Cameron JD, Riou ME, Tesson F, Goldfield GS, Rabasa-Lhoret $\mathrm{R}$, Brochu M and Doucet E (2013) The TaqIA RFLP is associated with attenuated intervention-induced body weight loss and increased carbohydrate intake in post-menopausal obese women. Appetite 60:111-116.
Cansell C and Luquet S (2016) Triglyceride sensing in the reward circuitry: A new insight in feeding behaviour regulation. Biochimie 120:75-80.

Carpenter CL, Wong AM, Li Z, Noble EP and Heber D (2013) Association of dopamine $\mathrm{D} 2$ receptor and leptin receptor genes with clinically severe obesity. Obesity 21:E467-473.

Cordeiro Q, Siqueira-Roberto J, Zung S and Vallada H (2009) Association between the DRD2-141C Insertion/Deletion polymorphism and schizophrenia. Arq Neuropsiquiatr 67:191194.

de Onis M, Blossner M and Borghi E (2010) Global prevalence and trends of overweight and obesity among preschool children. Am J Clin Nutr 92:1257-1264.

Du Y and Wan YJ (2009) The interaction of reward genes with environmental factors in contribution to alcoholism in mexican americans. Alcohol Clin Exp Res 33:2103-2112.

Dubertret C, Gouya L, Hanoun N, Deybach JC, Ades J, Hamon M and Gorwood P (2004) The 3' region of the DRD2 gene is involved in genetic susceptibility to schizophrenia. Schizophr Res 67:75-85.

Duran-Gonzalez J, Ortiz I, Gonzales E, Ruiz N, Ortiz M, Gonzalez A, Sanchez EK, Curet E, Fisher-Hoch S, Rentfro A, et al. (2011) Association study of candidate gene polymorphisms and obesity in a young Mexican-American population from South Texas. Arch Med Res 42:523-531.

Eisenstein SA, Bogdan R, Love-Gregory L, Corral-Frias NS, Koller JM, Black KJ, Moerlein SM, Perlmutter JS, Barch DMc and Hershey T (2016). Prediction of striatal D2 receptor binding by DRD2/ANKK1 TaqIA allele status. Synapse 70:418-431.

Fontana C, Vitolo MR, Campagnolo PD, Mattevi VS, Genro JP and Almeida S (2015) DRD4 and SLC6A3 gene polymorphisms are associated with food intake and nutritional status in children in early stages of development. J Nutr Biochem 26: 1607-1612.

Galvão AC, Krüger RC, Campagnolo PDB, Mattevi VS, Vitolo MR and Almeida S (2012) Association of MAOA and COMT gene polymorphisms with palatable food intake in children. J Nutr Biochem 23:272 - 277.

Garrido E, Palomo T, Ponce G, Garcia-Consuegra I, JimenezArriero MA and Hoenicka J (2011) The ANKK1 protein associated with addictions has nuclear and cytoplasmic localization and shows a differential response of Ala239Thr to apomorphine. Neurotox Res 20:32-39.

Gluskin BS and Mickey BJ (2016) Genetic variation and dopamine D2 receptor availability: A systematic review and meta-analysis of human in vivo molecular imaging studies. Transl Psychiatry 6:e747.

Grandy DK, Zhang Y and Civelli O (1993) PCR detection of the TaqA RFLP at the DRD2 locus. Hum Mol Genet 2:2197.

Gupta N, Goel K, Shah P and Misra A (2012) Childhood obesity in developing countries: epidemiology, determinants, and prevention. Endocr Rev 33:48-70.

Hardman CA, Rogers PJ, Timpson NJ and Munafo MR (2014) Lack of association between DRD2 and OPRM1 genotypes and adiposity. Int J Obes 38:730-736.

Himei A, Koh J, Sakai J, Inada Y, Akabame K and Yoneda H (2002) The influence on the schizophrenic symptoms by the DRD2Ser/Cys311 and -141C Ins/Del polymorphisms. Psychiatry Clin Neurosci 56:97-102. 
Hoenicka J, Ponce G, Jimenez-Arriero MA, Ampuero I, Rodriguez-Jimenez R, Rubio G, Aragues M, Ramos JA and Palomo T (2007) Association in alcoholic patients between psychopathic traits and the additive effect of allelic forms of the CNR1 and FAAH endocannabinoid genes, and the 3' region of the DRD2 gene. Neurotox Res 11:51-60.

Ishiguro H, Arinami T, Saito T, Akazawa S, Enomoto M, Mitushio H, Fujishiro H, Tada K, Akimoto Y, Mifune H, et al. (1998) Association study between the -141C Ins/Del and TaqI A polymorphisms of the dopamine D2 receptor gene and alcoholism. Alcohol Clin Exp Res 22:845-848.

Johann M, Putzhammer A, Eichhammer P and Wodarz N (2005) Association of the $-141 \mathrm{C}$ Del variant of the dopamine D2 receptor (DRD2) with positive family history and suicidality in German alcoholics. Am J Med Genet B Neuropsychiatr Genet 132B:46-49.

Jonsson EG, Nothen MM, Neidt H, Forslund K, Rylander G, Mattila-Evenden M, Asberg M, Propping P and Sedvall GC (1999a) Association between a promoter polymorphism in the dopamine D2 receptor gene and schizophrenia. Schizophr Res 40:31-36.

Jonsson EG, Nothen MM, Grunhage F, Farde L, Nakashima Y, Propping P and Sedvall GC (1999b) Polymorphisms in the dopamine D2 receptor gene and their relationships to striatal dopamine receptor density of healthy volunteers. Mol Psychiatry 4:290-296.

Kishida I, Kawanishi C, Furuno T, Kato D, Ishigami T and Kosaka K (2004) Association in Japanese patients between neuroleptic malignant syndrome and functional polymorphisms of the dopamine $\mathrm{D}(2)$ receptor gene. Mol Psychiatry 9:293-298.

Konishi T, Calvillo M, Leng AS, Lin KM and Wan YJ (2004a) Polymorphisms of the dopamine D2 receptor, serotonin transporter, and GABA(A) receptor beta(3) subunit genes and alcoholism in Mexican-Americans. Alcohol 32:45-52.

Konishi T, Luo HR, Calvillo M, Mayo MS, Lin KM and Wan YJ (2004b) ADH1B*1, ADH1C*2, DRD2 (-141C Ins), and 5-HTTLPR are associated with alcoholism in Mexican American men living in Los Angeles. Alcohol Clin Exp Res 28:1145-1152.

Lafuente A, Bernardo M, Mas S, Crescenti A, Aparici M, Gasso P, Goti J, Sanchez V, Catalan R and Carne X (2008a) -141C Ins/Del polymorphism of the dopamine $\mathrm{D} 2$ receptor gene is associated with schizophrenia in a Spanish population. Psychiatr Genet 18:122-127.

Lafuente A, Bernardo M, Mas S, Crescenti A, Aparici M, Gasso P, Deulofeu R, Mane A, Catalan R and Carne X (2008b) Polymorphism of dopamine D2 receptor (TaqIA, TaqIB, and141C Ins/Del) and dopamine degradation enzyme (COMT G158A, A-278G) genes and extrapyramidal symptoms in patients with schizophrenia and bipolar disorders. Psychiatry Res 161:131-141.

Lahiri DK and Nurnberger Jr JI (1991) A rapid non-enzymatic method for the preparation of HMW DNA from blood for RFLP studies. Nucleic Acids Res 19:5444.

Lee SH, Lee BH, Lee JS, Chai YG, Choi MR, Han DM, Ji H, Jang GH, Shin HE and Choi IG (2013) The association of DRD2 -141C and ANKK1 TaqIA polymorphisms with alcohol dependence in Korean population classified by the Lesch typology. Alcohol Alcohol 48:426-432.
Lencer R, Bishop JR, Harris MS, Reilly JL, Patel S, Kittles R, Prasad KM, Nimgaonkar VL, Keshavan MS and Sweeney JA (2014) Association of variants in DRD2 and GRM3 with motor and cognitive function in first-episode psychosis. Eur Arch Psychiatry Clin Neurosci 264:345-355.

Lencz T, Robinson DG, Xu K, Ekholm J, Sevy S, Gunduz-Bruce H, Woerner MG, Kane JM, Goldman D and Malhotra AK (2006) DRD2 promoter region variation as a predictor of sustained response to antipsychotic medication in first-episode schizophrenia patients. Am J Psychiatry 163:529-531.

Lencz T, Robinson DG, Napolitano B, Sevy S, Kane JM, Goldman D and Malhotra AK (2010) DRD2 promoter region variation predicts antipsychotic-induced weight gain in first episode schizophrenia. Pharmacogenet Genomics 20:569-572.

Lerman C, Jepson C, Wileyto EP, Epstein LH, Rukstalis M, Patterson F, Kaufmann V, Restine S, Hawk L, Niaura R, et al. (2006) Role of functional genetic variation in the dopamine D2 receptor (DRD2) in response to bupropion and nicotine replacement therapy for tobacco dependence: results of two randomized clinical trials. Neuropsychopharmacology 31:231-242.

Li H, Wang X, Zhou Y, Ni G, Su Q, Chen Z, Chen Z, Li J, Chen X, Hou X, et al. (2015) Association of LEPR and ANKK1 gene polymorphisms with weight gain in epilepsy patients receiving valproic acid. Int J Neuropsychopharmacol 18:pyv021.

Louzada ML, Campagnolo PD, Rauber F and Vitolo MR (2012) Long-term effectiveness of maternal dietary counseling in a low-income population: A randomized field trial. Pediatrics 129:e1477-1484.

Miranda RC, Vetter SB, Genro JP, Campagnolo PD, Mattevi VS, Vitolo MR and Almeida S (2015) SLC6A14 and 5-HTR2C polymorphisms are associated with food intake and nutritional status in children. Clin Biochem 48:1277-1282.

Mota NR, Araujo-Jr EV, Paixao-Cortes VR, Bortolini MC and Bau CH (2012) Linking dopamine neurotransmission and neurogenesis: The evolutionary history of the NTAD (NCAM1-TTC12-ANKK1-DRD2) gene cluster. Genet Mol Biol 35:912-918.

Muller DJ, Zai CC, Sicard M, Remington E, Souza RP, Tiwari AK, Hwang R, Likhodi O, Shaikh S, Freeman N, et al. (2012) Systematic analysis of dopamine receptor genes (DRD1-DRD5) in antipsychotic-induced weight gain. Pharmacogenomics J 12156-164.

Must A (1996) Morbidity and mortality associated with elevated body weight in children and adolescents. Am J Clin Nutr 63(3 Suppl):445S-447S

Neville MJ, Johnstone EC and Walton RT (2004) Identification and characterization of ANKK1: a novel kinase gene closely linked to DRD2 on chromosome band 11q23.1. Hum Mutat 23:540-545.

Oggioni C, Lara J, Wells JC, Soroka K and Siervo M (2014) Shifts in population dietary patterns and physical inactivity as determinants of global trends in the prevalence of diabetes: An ecological analysis. Nutr Metab Cardiovasc Dis 24:11051111.

Ohara K, Nagai M, Tani K, Nakamura Y, Ino A and Ohara K (1998) Functional polymorphism of -141C Ins/Del in the dopamine D2 receptor gene promoter and schizophrenia. Psychiatry Res 81:117-123. 
Pohjalainen T, Rinne JO, Nagren K, Lehikoinen P, Anttila K, Syvalahti RK and Hietala J (1998) The A1 allele of the human D2 dopamine receptor gene predicts low D2 receptor availability in healthy volunteers. Mol Psychiatry 3:256260.

Ponce G, Quinones-Lombrana A, Martin-Palanco MG, RubioSolsona E, Jimenez-Arriero MA, Palomo T and Hoenicka J (2016) The addiction-related gene Ankk1 is oppositely regulated by D1R- and D2R-like dopamine receptors. Neurotox Res 29:345-350.

Popkin BM (2006) Global nutrition dynamics: the world is shifting rapidly toward a diet linked with noncommunicable diseases. Am J Clin Nutr 84:289-298.

Prasad P, Ambekar A and Vaswani M (2010) Dopamine D2 receptor polymorphisms and susceptibility to alcohol dependence in Indian males: A preliminary study. BMC Med Genet 11:24.

Ritchie T and Noble EP (2003) Association of seven polymorphisms of the $\mathrm{D} 2$ dopamine receptor gene with brain receptor-binding characteristics. Neurochem Res 28:73-82.

Rossner S (1998) Childhood obesity and adulthood consequences. Acta Paediatr 87:1-5.

Roth CL, Hinney A, Schur EA, Elfers CT and Reinehr T (2013) Association analyses for dopamine receptor gene polymorphisms and weight status in a longitudinal analysis in obese children before and after lifestyle intervention. BMC Pediatr 13:197.

Saiz PA, Garcia-Portilla MP, Arango C, Morales B, Arias B, Corcoran P, Fernandez JM, Alvarez V, Coto E, Bascaran MT, et al. (2010) Genetic polymorphisms in the dopamine-2 receptor (DRD2), dopamine-3 receptor (DRD3), and dopamine transporter (SLC6A3) genes in schizophrenia: Data from an association study. Prog Neuropsychopharmacol Biol Psychiatry 34:26-31.

Salamone JD (1994) The involvement of nucleus accumbens dopamine in appetitive and aversive motivation. Behav Brain Res 61:117-133.

Stelzel C, Basten U, Montag C, Reuter M and Fiebach CJ (2010) Frontostriatal involvement in task switching depends on genetic differences in $\mathrm{d} 2$ receptor density. $\mathrm{J}$ Neurosci 30:14205-14212.

Stice E, Spoor S, Bohon C and Small DM (2008) Relation between obesity and blunted striatal response to food is moderated by TaqIA A1 allele. Science 322:449-452.

Suda A, Kawanishi C, Kishida I, Sato R, Yamada T, Nakagawa M, Hasegawa H, Kato D, Furuno T and Hirayasu Y (2009) Dopamine D2 receptor gene polymorphisms are associated with suicide attempt in the Japanese population. Neuropsychobiology 59:130-134.

Terry P, Gilbert DB and Cooper SJ (1995) Dopamine receptor subtype agonists and feeding behavior. Obes Res 3 (Suppl 4):515S-523S.

Ujike H, Katsu T, Okahisa Y, Takaki M, Kodama M, Inada T, Uchimura N, Yamada M, Iwata N, Sora I, et al. (2009) Genetic variants of D2 but not D3 or D4 dopamine receptor gene are associated with rapid onset and poor prognosis of methamphetamine psychosis. Prog Neuropsychopharmacol Biol Psychiatry 33:625-629.

van Strien T, Snoek HM, van der Zwaluw CS and Engels RC (2010) Parental control and the dopamine D2 receptor gene (DRD2) interaction on emotional eating in adolescence. Appetite 54:255-261.

Vitolo MR, Rauber F, Campagnolo PD, Feldens CA and Hoffman DJ (2010) Maternal dietary counseling in the first year of life is associated with a higher healthy eating index in childhood. J Nutr 140:2002-2007.

Volkow ND, Wang GJ, Fowler JS, Logan J, Jayne M, Franceschi D, Wong C, Gatley SJ, Gifford AN, Ding YS, et al. (2002) "Nonhedonic" food motivation in humans involves dopamine in the dorsal striatum and methylphenidate amplifies this effect. Synapse 44:175-180.

Wang GJ, Volkow ND, Logan J, Pappas NR, Wong CT, Zhu W, Netusil N and Fowler JS (2001) Brain dopamine and obesity. Lancet 357:354-357.

Wang Y, Liu L, Xin L, Fan D, Ding N, Hu Y, Cai G, Wang L, Xia $\mathrm{Q}$, Li X, et al. (2016) The -141C Ins/Del and Taq1A polymorphism in the dopamine D2 receptor gene may confer susceptibility to schizophrenia in Asian populations. J Clin Neurosci 30:1-7.

Winkler JK, Woehning A, Schultz JH, Brune M, Beaton N, Challa TD, Minkova S, Roeder E, Nawroth PP, Friederich HC, et al. (2012) TaqIA polymorphism in dopamine D2 receptor gene complicates weight maintenance in younger obese patients. Nutrition 28:996-1001.

Wu S, Xing Q, Gao R, Li X, Gu N, Feng G and He L (2005) Response to chlorpromazine treatment may be associated with polymorphisms of the DRD2 gene in Chinese schizophrenic patients. Neurosci Lett 376: 1-4.

Xiao L, Shen T, Peng DH, Shu C, Jiang KD and Wang GH (2013) Functional -141C Ins/Del polymorphism in the dopamine D2 receptor gene promoter and schizophrenia in a Chinese Han population. J Int Med Res 41:1171-1178.

Zhang JP, Lencz T and Malhotra AK (2010) Dopamine D2 receptor genetic variation and clinical response to antipsychotic drug treatment: A meta-analysis. Am J Psychiatry 167:763-772.

Zhao X, Huang Y, Chen K, Li D, Han C and Kan Q (2016) -141C insertion/deletion polymorphism of the dopamine $\mathrm{D} 2$ receptor gene is associated with schizophrenia in Chinese Han population: Evidence from an ethnic group-specific metaanalysis. Asia Pac Psychiatry 8:189-198.

\section{Internet Resources}

World Health Organization (2006) The WHO Child Growth Standards. from http://www.who.int/childgrowth/standards/en/.

Associate Editor: Angela M. Vianna-Morgante

License information: This is an open-access article distributed under the terms of the Creative Commons Attribution License (type CC-BY), which permits unrestricted use, distribution and reproduction in any medium, provided the original article is properly cited. 